\title{
Analisis Teknis dan Ekonomis Pada Kapal Wisata Dengan Menggunakan HybridSystem Di Alun-Alun Sungai Kapuas
}

\author{
Ferdyanto \\ Program Magister Teknik Elektro Fakultas Teknik Universitas Tanjungpura. \\ e-mail : ferdy_ncex@yahoo.co.id
}

\begin{abstract}
Ketersediaan energi tak terbarukan yang kian menipis dapat menjadi permasalahan bagi kehidupan manusia. Kapal Wisata di Kota Pontianak menggunakan $B B M$ HSD. Untuk mendapatkan penghematan biaya penggunaan BBM HSD menggunakan metode hybrid system. Keputusan pelaksanaan proyek dan kelayakan investasi menggunakan metode model ekonomi.

Berdasarkan hasil rancangan diperoleh kapasitas baterai sebesar 48 volt 800 Ah. Waktu kemampuan baterai menggerakkan motor listrik DC selama 1 jam 25 menit dengan kecepatan 6,7 knots dan dapat menempuh sejauh 17,4 km.

Penghematan biaya penggunaan BBM HSD setelah penerapan hybrid system dalam setahun sebesar $R p$ 37,777,500,- (60\%). Parameter yang digunakan untuk analisis ekonomis adalah Break Even Point (BEP) pada periode tahun ke-9 dengan nilai surplus $R p$ 13.732.680,Gross Benefit Cost Ratio (Gross B/C) adalah 1,32, Return on Investment (ROI) sebesar 32\%, Net Present Value (NPV)senilai Rp 100.381.535,- dan Internal Rate of Return (IRR) sebesar $17,57 \%$ dalam periode 20 tahun.

Hasil keputusan secara keseluruhan dari penerapan hybrid system adalah proyek dapat dilaksanakan serta investasi layak dan menguntungkan.
\end{abstract}

Keywords- kapal wisata, motor listrik DC, hybrid system

\section{Pendahuluan}

Dalam pemanfaatan energi diperlukan kebijakan dan pengaturan yang lebih baik dan terencana, yang dikenal sebagai konservasi energi. Konservasi energi adalah penggunaan energi disertai usaha-usaha mencari teknologi baru dengan memanfaatkan sumber energi terbarukan (misalnya sinar matahari, tenaga air, panas bumi) dengan lebih efisien.

Menurut Sudiyono dan BambangAntoko (2008), hybridsystem merupakan sebuah konsep penggabungan dua atau lebih sumber energi untuk tercapainya sebuah efisiensi dalam berbagai hal, sebagai contoh mesin diesel yang umum digabungkan dengan sumber energi lain seperti energi matahari.Hybridsystem adalah sistem yang menggunakan dua atau lebih sumber energi atau tenaga penggerak yang berbeda untuk menggerakkan propeller kapal wisata. ${ }^{[1]}$
2. Teori Dasar

\subsection{Konsep Perancangan}

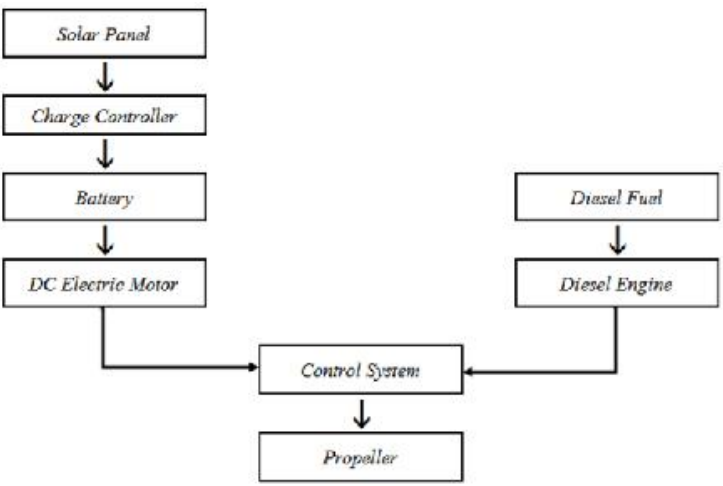

Gambar 1. Skema hybrid system ${ }^{[2]}$

\subsection{Kecepatan dan Jarak Tempuh Kapal Wisata ${ }^{[3]}$}

Untuk spesifikasi mesin diesel dan motor listrik DC yang berbeda, perhitungan asumsi kecepatan kapal wisata dengan motor listrik DC dapat menggunakan persamaan sebagai berikut :

dimana :

$$
\frac{\mathrm{rpm}_{\mathrm{D}}}{\mathrm{V}_{\mathrm{D}}}=\frac{\mathrm{rpm}_{\mathrm{L}}}{\mathrm{V}_{\mathrm{L}}}
$$

$\mathrm{rpm}_{\mathrm{D}}=\mathrm{rpm}$ mesin diesel (revolution /minute)

$\mathrm{rpm}_{\mathrm{L}}=\mathrm{rpm}$ motor listrik DC (revolution/minute)

$\mathrm{V}_{\mathrm{D}} \quad=$ kecepatan mesin diesel (knot)

$\mathrm{V}_{\mathrm{D}} \quad=$ kecepatan motor listrik DC (knot)

Perhitungan jarak tempuh kapal wisata menggunakan persamaan sebagai berikut :

$$
\mathrm{S}=\mathrm{V} \times \mathrm{x} \text { t }
$$

dimana :

$\mathrm{S} \quad=$ jarak tempuh $(\mathrm{km})$

$\mathrm{V}=\operatorname{kecepatan}($ knot $)$

$\mathrm{t}=$ waktu tempuh (menit)

1 knot $=1$ nauticalmile/jam.

1 nauticalmile $=1.852 \mathrm{~m}$ atau $1,852 \mathrm{~km}$.

\subsection{Penentuan Arus Motor Listrik DC ${ }^{[3]}$}

Perhitungan konstanta pada motor listrik DC dapat dihitung dengan mencari radian per second (rps) motor listrik DC terlebih dahulu menggunakan persamaan berikut : 


$$
\mathrm{rps}=2 \times \pi \times \frac{\mathrm{rpm}}{60}
$$

dimana :

$\mathrm{rps}=\operatorname{radian} / \operatorname{detik}($ radian $/$ second $)$

$\pi \quad=3,14$

$\mathrm{rpm}=\operatorname{putaran} /$ menit $($ revolution $/$ minute $)$

Konstanta motor listrik DC dapat dihitung dari persamaan berikut :

$$
\mathrm{k}=\frac{\mathrm{V}}{\mathrm{rps}}
$$

dimana :

$$
\begin{aligned}
\mathrm{V} & =\text { tegangan motor listrik DC }(\mathrm{V}) \\
\mathrm{k} & =\text { konstanta motor listrik DC } \\
\mathrm{rps} & =\operatorname{radian} / \text { detik }(\text { radian } / \text { second) }
\end{aligned}
$$

Besarnya arus yang digunakan motor listrik DC dapat dihitung dengan menggunakan persamaan berikut

dimana :

$$
I=\frac{Q_{\text {mesin }}}{k}
$$

$$
\begin{array}{ll}
\mathrm{I} & =\text { arus motor listrik DC(A) } \\
\mathrm{Q} & =\text { torsi motor listrik DC }(\mathrm{Nm}) \\
\mathrm{k} & =\text { konstanta motor listrik }
\end{array}
$$

\subsection{Baterai $^{[4]}$}

Persamaan yang digunakan untuk menghitung jumlah kebutuhan baterai adalah sebagai berikut :

dimana :

$$
\mathrm{n}=\frac{\mathrm{P} \times 2}{\mathrm{~V} \times \mathrm{I}}
$$

$$
\begin{array}{ll}
\mathrm{n} & =\text { jumlah kebutuhan baterai } \\
\mathrm{P} & =\text { kebutuhan daya motor listrik DC }(\mathrm{W}) \\
\mathrm{V} & =\text { tegangan baterai }(\mathrm{V}) \\
\mathrm{I} & =\text { kapasitas baterai }(\mathrm{Ah})
\end{array}
$$

Laju pengisian baterai dapat dihitung dengan persamaan :

$$
\mathrm{T}=\frac{(\mathrm{I} \times \mathrm{V}) \times \mathrm{n}}{\mathrm{Wp} / \mathrm{jam}}
$$

dimana :

$$
\begin{array}{ll}
\mathrm{T} & =\text { waktu pengisian baterai }(\mathrm{Jam}) \\
\mathrm{n} & =\text { jumlah baterai } \\
\mathrm{I} & =\text { kapasitas baterai }(\mathrm{Ah}) \\
\mathrm{V} & =\text { tegangan baterai }(\mathrm{V})
\end{array}
$$

$\mathrm{Wp} / \mathrm{jam}=$ daya keseluruhan panel surya dalam 1 jam

Untuk mengetahui jangka waktu kapasitas baterai yang digunakan untuk kebutuhan arus motor listrik DC digunakan persamaan sebagai berikut :

dimana :

$$
t_{b}=\frac{I_{b}}{I_{m}}
$$

$$
\begin{array}{ll}
\mathrm{t}_{\mathrm{b}} & =\text { waktu kemampuan kapasitas baterai (Jam) } \\
\mathrm{I}_{\mathrm{b}} & =\text { kapasitas baterai (Ah) } \\
\mathrm{I}_{\mathrm{m}} & =\text { arus motor listrik DC }(\mathrm{A})
\end{array}
$$

SOC dari baterai 2 volt ditentukan sebesar $30 \%$ dengan mengacu pada tabel 1 StateofCharge Baterai 2 volt $^{[5]}$
Tabel 1. StateofCharge Baterai 2 volt ${ }^{[5]}$

\begin{tabular}{cc}
\hline CELL VOLTAGE & STATE-OF-CHARGE \\
\hline 2.027 & 45 \\
\hline 2.021 & 40 \\
\hline 2.013 & 35 \\
\hline 2.005 & 30 \\
\hline 1.997 & 25 \\
\hline 1.988 & 20 \\
\hline 1.978 & 15 \\
\hline
\end{tabular}

Kapasitas baterai yang digunakan untuk motor listrik DC menjadi $70 \%$ karena pengaruh dari SOC, maka untuk mendapatkan waktu kemampuan baterai menggerakkan motor listrik DC digunakan persamaan sebagai berikut :

$$
\mathrm{t}=\frac{70 \% \times \mathrm{P}_{\mathrm{b}}}{\mathrm{P}_{\mathrm{m}}}
$$

dimana :

$$
\begin{aligned}
& \mathrm{t}=\text { waktu kemampuan baterai (Jam) } \\
& \mathrm{P}_{\mathrm{b}}=\text { kapasitas baterai }(\mathrm{Wh}) \\
& \mathrm{P}_{\mathrm{m}}=\text { daya motor listrik DC }(\mathrm{W})
\end{aligned}
$$

\subsection{Penentuan Jumlah Modul Panel Surya ${ }^{[5][6]}$}

Jumlah kebutuhan modul panel surya dapat dihitung dengan persamaan berikut :

$$
n_{P V}=\frac{P}{P_{P V} \times t_{P V}}
$$

dimana :

$\mathrm{n}_{\mathrm{PV}}=$ jumlah kebutuhan panel surya (modul)

$\mathrm{P} \quad=\quad$ daya yang dibutuhkan $(\mathrm{W})$

$\mathrm{P}_{\mathrm{PV}}=$ daya panel surya $(\mathrm{Wp})$

$\mathrm{t}_{\mathrm{PV}}=$ jumlah jam suplai sinar matahari

Penyinaran matahari di Indonesia adalah 4 jam. Beberapa kota besar memiliki penyinaran hanya 3 jam dan beberapa daerah yang dekat dengan garis khatulistiwa memiliki penyinaran hingga 5 jam, namun penyinaran selama 4 jam dapat menjadi standar acuan.

\subsection{Penentuan Spesifikasi Charge Controller ${ }^{[7]}$}

Untuk melindungi baterai dan sebagai pengaman dari tegangan yang berlebih, maka digunakanchargecontrolleryang disesuaikan dengan spesifikasi panel surya dan baterai.

\subsection{Model Ekonomi}

\subsubsection{Biaya Instalasi Awal (Initial Installation Cost) ${ }^{[8]}$}

Initial Installation Cost (IIC) adalah biaya instalasi awal yaitu biaya yang dikeluarkan untuk membeli sistem hibrid diawal tahun pertama. Persamaan untuk menghitung biaya investasi awal (IIC) adalah sebagai berikut :

$$
\mathrm{IIC}=\mathrm{C}_{\mathrm{HS}}+\mathrm{C}_{\text {ins }}+\mathrm{C}_{\mathrm{L}}
$$

dimana :

IIC = biaya instalasi awal $(\mathrm{Rp})$ 
$\mathrm{C}_{\mathrm{HS}}=$ biaya investasi alat sistem hibrid (Rp)

$\mathrm{C}_{\text {ins }}=$ biaya instalasi ( $\left.\mathrm{Rp}\right)$

$\mathrm{C}_{\mathrm{L}}=$ biaya tenaga kerja (Rp/orang-jam)

2.8.2. Arus Kas Bersih Tahunan (Annual Net Cash Flow) ${ }^{[9]}$

Annual Net Cash Flow $\left(\mathrm{CF}_{\mathrm{N}}\right)$ adalah jumlah arus kas masuk (pendapatan) dikurang arus kas keluar (biaya) dalam setahun.

Persamaan untuk menghitung arus kas bersih tahunan adalah sebagai berikut :

dimana :

$$
\mathrm{CF}_{\mathrm{N}}=\mathrm{CF}_{\text {in }}-\mathrm{CF}_{\text {out }}
$$

$\mathrm{CF}_{\mathrm{N}}=$ arus kas bersih tahunan $(\mathrm{Rp})$

$\mathrm{CF}_{\text {in }}=$ nilai penghematan HSD dalam setahun (Rp)

$\mathrm{CF}_{\text {out }}=$ biaya operasional dan pemeliharaan dalam setahun (Rp)

\subsubsection{Periode Pengembalian (PaybackPeriod $)^{[10]}$}

Payback Period (PP) dapat diartikan dengan lamanya waktu yang dibutuhkan untuk mengembalikan biaya investasi.

dimana :

$$
\mathrm{PP}=\frac{\mathrm{IIC}}{\mathrm{CF}_{\mathrm{N}}}
$$

$\mathrm{PP}=$ periode pengembalian (tahun)

IIC = biaya investasi awal(Rp)

$\mathrm{CF}_{\mathrm{N}}=$ arus kas bersih tahunan $(\mathrm{Rp})$

\subsubsection{Pembayaran Tahunan (Yearly Payment) ${ }^{[9]}$}

Yearly Payment (PI) adalah pembayaran pinjaman termasuk pokok dan bunga dalam setahun.

Perhitungan pembayaran tahunan dapat dihitung menggunakan persamaan sebagai berikut :

$$
P I=L \quad x \frac{r \times(1+r)^{N}}{(1+r)^{N}-1}
$$

dimana :

$\mathrm{PI}=$ pokok dan bunga $(\mathrm{Rp})$

$\mathrm{L}=$ jumlah yang dipinjamkan $(\mathrm{Rp})$

$\mathrm{r}=$ tingkat bunga $(\%)$

$\mathrm{N}=$ durasi pinjaman (tahun)

\subsubsection{Titik Impas (Break Even Point ${ }^{[9]}$}

Break Even Point (BEP) digunakan untuk menentukan tingkat produksi yang mengakibatkan perusahaan pada kondisi impas. Persamaan yang digunakan untuk menghitung BEP adalah sebagai berikut :

$$
\mathrm{BEP}=\sum_{\mathrm{i}=1}^{\mathrm{n}} \mathrm{CF}_{\text {out }}-\sum_{\mathrm{i}=1}^{\mathrm{n}} \mathrm{CF}_{\text {in }}=0
$$

dimana :

$\mathrm{BEP}=$ Titik impas (BreakEvenPoint)

$\mathrm{CF}_{\text {out }}=$ arus kas keluar pada periode $\mathrm{n}(\mathrm{Rp})$

$\mathrm{CF}_{\text {in }}=$ arus kas masuk pada periode $\mathrm{n}(\mathrm{Rp})$

\subsubsection{Arus Kas Tahunan (Annual Cash Flow) ${ }^{[9]}$}

Annual Cash Flow $\left(\mathrm{CF}_{\mathrm{A}}\right)$ adalah arus kas masuk dari pendapatan bersih dalam setahun dikurang pembayaran pinjaman termasuk pokok dan bunga dalam setahun.

Persamaan yang digunakan untuk menghitung arus kas tahunan $\left(\mathrm{CF}_{\mathrm{A}}\right)$ adalah sebagai berikut :

dimana :

$$
\mathrm{CF}_{\mathrm{A}}=\mathrm{CF}_{\mathrm{N}}-\mathrm{PI}
$$

$\mathrm{CF}_{\mathrm{A}}=$ arus kas tahunan $(\mathrm{Rp})$

$\mathrm{CF}_{\mathrm{N}}=$ arus kas bersih tahunan(Rp)

$\mathrm{PI}=$ pokok dan bunga $(\mathrm{Rp})$

\subsubsection{Arus Kas Kumulatif (Cumulative Cash Flow $)^{[9]}$}

Cumulative Cash Flow $\left(\mathrm{CF}_{\mathrm{C}}\right)$ adalah jumlah arus kas tahunan pada periode yang diharapkan.

Persamaan untuk menghitung arus kas kumulatif $\left(\mathrm{CF}_{\mathrm{C}}\right)$ adalah sebagai berikut :

$\mathrm{CF}_{\mathrm{C}, \mathrm{n}}=\sum_{\mathrm{i}=1}^{\mathrm{n}} \mathrm{CF}_{\mathrm{A}}$

dimana :

$\mathrm{CF}_{\mathrm{C}}=$ arus kas kumulatif(Rp)

$\mathrm{CF}_{\mathrm{A}}=\operatorname{arus}$ kas tahunan $(\mathrm{Rp})$

$\mathrm{n} \quad=$ periode yang diharapkan (tahun) berikut :

Atau dengan menggunakan persamaan sebagai

$$
\begin{aligned}
\mathrm{CF}_{\text {out }} & =\sum_{\mathrm{i}=1}^{\mathrm{n}} \mathrm{IIC}+\sum_{i=1}^{n} \mathrm{PI}+\sum_{\mathrm{i}=1}^{\mathrm{n}} \text { Equipment }+\sum_{\mathrm{i}=1}^{\mathrm{n}} \text { Maintenance } \\
\mathrm{CF}_{\mathrm{C}, \mathrm{n}} & =\sum_{\mathrm{i}=1}^{\mathrm{n}} \mathrm{CF}_{\text {in }}-\sum_{\mathrm{i}=1}^{\mathrm{n}} \mathrm{CF}_{\text {out }}
\end{aligned}
$$

dimana :

$\mathrm{CF}_{\mathrm{C}}=$ arus kas kumulatif(Rp)

$\mathrm{CF}_{\text {in }}=$ arus kas masuk pada periode $n(\mathrm{Rp})$

$\mathrm{CF}_{\text {out }}=$ arus kas keluar pada periode $\mathrm{n}(\mathrm{Rp})$

$\mathrm{n} \quad=$ periode yang diharapkan (tahun)

\subsubsection{Gross Benefit Cost Ratio (Gross B/C $)^{[11]}$}

Gross B/C merupakan perbandingan antara arus kas masuk pada periode $\mathrm{n}$ dengan arus kas keluar pada periode $n$.

Persamaan untuk menghitung Gross B/C adalah sebagai berikut :

$$
\text { Gross } \mathrm{B} / \mathrm{C}=\frac{\sum_{i=1}^{\mathrm{n}} \mathrm{C} \mathrm{F}_{\text {in }}}{\sum_{\mathrm{i}=1}^{\mathrm{n}} \mathrm{CF}_{\text {out }}}
$$

\section{Gross B/C = Gross Benefit Cost Ratio}

$\mathrm{CF}_{\text {in }} \quad=$ arus kas masuk pada periode $\mathrm{n}(\mathrm{Rp})$

$\mathrm{CF}_{\text {out }} \quad=$ arus kas keluar pada periode $\mathrm{n}(\mathrm{Rp})$

$\mathrm{n} \quad=$ periode yang diharapkan (tahun)

Berikut ditunjukkan arti dari perhitungan Gross B/C terhadap keputusan investasi yang akan dilakukan :

a. Gross B/C > 1, maka proyek layak untuk dilaksanakan.

b. Gross $\mathrm{B} / \mathrm{C}<1$, maka proyek tidak layak untuk dilaksanakan.

c. Gross $\mathrm{B} / \mathrm{C}=1$, maka proyek dalam keadaan BEP. 


\subsubsection{Return On Investment (ROI) $)^{[12][13]}$}

ROI adalah perhitungan yang digunakan untuk mengevaluasi efisiensi dari suatu investasi.

ROI dapat dicari dengan menggunakan persamaan berikut :

$$
\text { ROI }=\frac{\sum_{t=0}^{N} \mathrm{CF}_{\text {in }}-\sum_{t=0}^{N} \mathrm{CF}_{\text {out }}}{\sum_{\mathrm{t}=0}^{N} \mathrm{CF}_{\text {out }}} \times 100 \%
$$

dimana :

$$
\begin{array}{ll}
\mathrm{ROI} & =\text { Return On Investment }(\%) \\
\mathrm{CF}_{\text {in }} & =\text { kas masuk }(\mathrm{Rp}) \\
\mathrm{CF}_{\text {out }} & =\text { kas keluar }(\mathrm{Rp}) \\
\mathrm{t} & =\text { periode arus kas (tahun) } \\
\mathrm{N} & =\text { jumlah periode }
\end{array}
$$

Jika ROI yang didapatkan $<0 \%$, maka diperlukan biaya investasi tambahan dan hal ini disebut negative ROI. Jika didapatkan hasil negative ROI maka proyek tidak layak dilaksanakan atau ditolak.

\subsubsection{Net Present Value $(\mathrm{NPV})^{[14]}$}

Menghitung NPV dilakukan dengan cara menghitung arus kas bersih tahunan tiap tahun yakni dengan membandingkan antara pengeluaran dengan pemasukan pada tiap-tiap tahun, lalu menghitung tingkat diskon (i) maka akan didapat periode arus kas (t).

Persamaan untuk menghitung Net Present Value (NPV) menggunakan persamaan sebagai berikut :

$$
\operatorname{NPV}(i, \mathrm{~N})=\sum_{\mathrm{t}=0}^{\mathrm{N}} \frac{\mathrm{CF}_{\mathrm{N}}}{(1+i)^{\mathrm{t}}}
$$

dimana :

$$
\begin{array}{ll}
\mathrm{NPV} & =\text { Net Present Value }(\mathrm{Rp}) \\
\mathrm{CF}_{\mathrm{N}} & =\text { arus kas bersih tahunan(Rp) } \\
i & =\text { tingkat diskon }(\%) \\
\mathrm{t} & =\text { periode arus kas (tahun) } \\
\mathrm{N} & =\text { jumlah periode }
\end{array}
$$

Berikut ditunjukkan arti dari perhitungan NPV terhadap keputusan investasi yang akan dilakukan :

a. NPV > 0, maka investasi yang dilakukan memberikan manfaat bagi perusahaan. Proyek bisa dijalankan.

b. NPV < 0 maka investasi yang dilakukan tidak memberikan manfaat bagi perusahaan. Proyek ditolak.

c. $\mathrm{NPV}=0$, maka investasi yang dilakukan tidak mengakibatkan perusahaan untung atau rugi.

\subsubsection{Internal Rate of Return (IRR) ${ }^{[15]}$}

IRR adalah tingkat diskon yang akan menghasilkan $\mathrm{NPV}=0$.Proyek layak diterima apabila IRR lebih besar dari suku bunga di bank atau tingkat pengembalian untuk suatu proyek investasi.

IRR dapat cari dengan persamaan berikut :

$$
\mathrm{IRR}=\mathrm{r}_{\mathrm{a}}+\frac{\mathrm{NPV}_{\mathrm{a}}}{\mathrm{NPV}_{\mathrm{a}}-\mathrm{NPV}_{\mathrm{b}}} \times\left(\mathrm{r}_{\mathrm{b}}-\mathrm{r}_{\mathrm{a}}\right)
$$

dimana :

$\mathrm{r}_{\mathrm{a}} \quad=$ tingkat suku bunga rendah $(\%)$

$\mathrm{r}_{\mathrm{b}} \quad=$ tingkat suku bunga tinggi $(\%)$

$\mathrm{NPV}_{\mathrm{a}}=\mathrm{NPV} \operatorname{padar}_{\mathrm{a}}(\mathrm{Rp})$

$\mathrm{NPV}_{\mathrm{b}}=$ NPV pada $\mathrm{r}_{\mathrm{b}}(\mathrm{Rp})$

Berikut ditunjukkan arti dari perhitungan IRR terhadap keputusan investasi yang akan dilakukan :

a. IRR > tingkat suku bunga, maka investasi layak untuk dilaksanakan.

b. IRR < tingkat suku bunga, maka investasi tidak layak untuk dilaksanakan.

c. IRR = tingkat suku bunga, maka investasi yang dilakukan tidak mengakibatkan untung atau rugi.

\section{Desain Teknis dan Analisis \\ 3.1. Arus Motor Listrik DC}

Motor listrik DC yang digunakan berjenis Permanent Magnet Motor dengan daya19 kW, tegangan 48 volt, kecepatan3.600 rpm dan torsi52 $\mathrm{Nm}$.

Untuk mendapatkan nilai konstanta motor listrik DC dengan digunakan persamaan 3 sebagai berikut :

$$
\begin{aligned}
\mathrm{rps}=2 \times 3,14 \times \frac{3.600}{60} \\
=376,8
\end{aligned}
$$

Perhitungan konstanta motor listrik DC dapat dihitung dari persamaan 4 sebagai berikut :

$$
\begin{aligned}
\mathrm{k} & =\frac{48 \text { volt }}{376,8 \mathrm{rps}} \\
& =0,127 \approx 0,13
\end{aligned}
$$

Nilai konstanta motor listrik DC akan digunakan untuk menghitung arus konsumsi motor listrik DC denganpersamaan 5 sebagai berikut :

$$
\begin{aligned}
I & =\frac{52 \mathrm{Nm}}{0,13} \\
& =408,20 \mathrm{~A}
\end{aligned}
$$

\subsection{Waktu Kemampuan Baterai Menggerakkan Motor Listrik DC}

Untuk menghitung jumlah kebutuhan baterai menggunakan persamaan 6 sebagai berikut :

$$
\begin{aligned}
n & =\frac{19.000 \times 2}{48 \times 800} \\
& =0,9895 \approx 1 \text { unit bank baterai }
\end{aligned}
$$

Laju pengisian baterai dihitung dengan persamaan 7 sebagai berikut :

$$
\begin{aligned}
\mathrm{T}= & \frac{(800 \times 48) \times 1}{7.200} \\
= & 5,33 \mathrm{jam}
\end{aligned}
$$

Perhitungan kebutuhan arus motor listrik DC dengan persamaan 8 adalah sebagai berikut :

$$
\begin{aligned}
t_{b} & =\frac{800}{408,20} \\
& =1,96 \approx 1 \text { jam } 58 \text { menit }
\end{aligned}
$$


Perhitungan waktu kemampuan baterai menggunakan persamaan 9 adalah sebagai berikut :

$$
\begin{aligned}
\mathrm{t} & =\frac{70 \% \times 38.400}{19.000} \\
& =1,41 \approx 1 \text { jam } 25 \text { menit }
\end{aligned}
$$

\subsection{Jumlah Modul Panel Surya}

Jumlah kebutuhan modul panel surya dapat dihitung dengan menggunakan persamaan 10 sebagai berikut :

$$
\begin{aligned}
\mathrm{n}_{\mathrm{PV}} & =\frac{38.400}{600 \times 5,33} \\
& =11,64 \approx 12 \text { modul panel surya }
\end{aligned}
$$

Tabel 2. Suplai daya modul panel surya

\begin{tabular}{cccc}
\hline No & $\begin{array}{c}\text { Watt Peak } \\
\text { (Watt) }\end{array}$ & $\begin{array}{c}\text { Jumlah Modul } \\
\text { Panel Surya }\end{array}$ & $\begin{array}{c}\text { Daya Total } \\
\text { (Watt) }\end{array}$ \\
\hline \hline 1 & 600 & 12 & 7,200 \\
\hline 2 & 600 & 12 & 7,200 \\
\hline 3 & 600 & 12 & 7,200 \\
\hline 4 & 600 & 12 & 7,200 \\
\hline & & & $\mathbf{2 8 . 8 0 0}$ \\
\hline
\end{tabular}

\subsection{Hasil Rancangan}

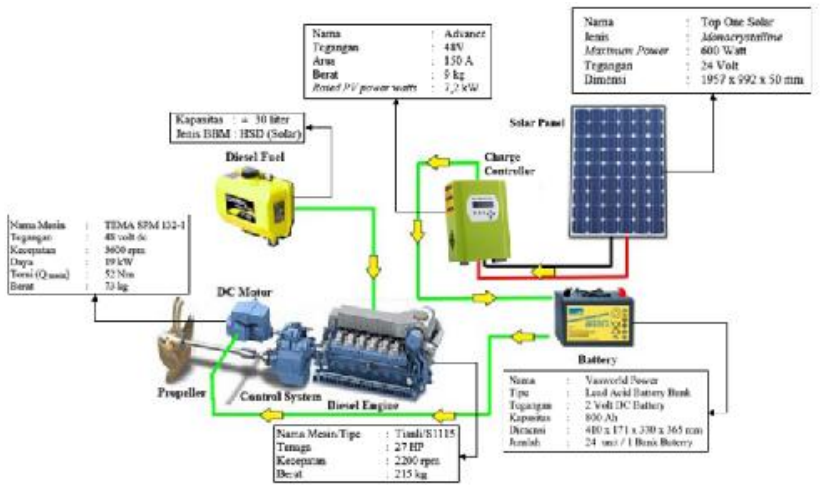

Gambar 2. Hasil rancangan hybridsystem kapal wisata

\subsection{Kecepatan dan Jarak Tempuh Kapal Wisata Menggunakan Motor Listrik DC}

Perhitungan kecepatan motor listrik DC jika diketahui kecepatan mesin diesel sebesar 4,07 knots dengan menggunakan persamaan 1 sebagai berikut :

$$
\begin{aligned}
2.200 \mathrm{~V}= & 14.652 \\
\mathrm{~V} & =6,7 \text { knots } \approx 12,41 \mathrm{~km} / \mathrm{jam}
\end{aligned}
$$

Jarak tempuh yang didapat menggunakan motor listrik DC dengan $70 \%$ kapasitas baterai dapat dihitung dengan persamaan 2 sebagai berikut :

$$
\begin{aligned}
\mathrm{S} & =12,41 \mathrm{~km} / \mathrm{jam} \times 1,41 \mathrm{jam} \\
& =17,4 \mathrm{~km}
\end{aligned}
$$

\subsection{Analisis Ekonomis}

Jarak tempuh kapal wisata bermesin diesel sejauh 29 $\mathrm{km} /$ hari. Penggunaan biaya BBM HSD kapal wisata bermesin diesel sebelum penerapan hybridsystemsebagai berikut :

$29 \mathrm{~km} / \mathrm{hari} \approx 25$ liter/hari $\approx \mathrm{Rp} \quad 172.500$,-/hari

Jarak tempuh kapal wisata yang disuplai menggunakan motor listrik DC sejauh 17,4 km/hari, sehingga jarak tempuh kapal wisata bermesin diesel setelah disuplai sebagai berikut :

$29 \mathrm{~km} / \mathrm{hari}-17,4 \mathrm{~km} / \mathrm{hari}=11,6 \mathrm{~km} / \mathrm{hari}$.

Penggunaan biaya BBM HSD pada kapal wisata bermesin diesel setelah penerapan hybrid system sebagai berikut :

$$
11,6 \mathrm{~km} / \text { hari } \approx 10 \text { liter/hari } \approx \mathrm{Rp} \quad 69.000 \text {,-/hari. }
$$

Penghematan biaya penggunaan BBM HSD kapal wisata setelah penerapan hybridsystem sebesar :

$$
\begin{array}{ll}
\text { Rp 172.500-Rp 69.000 } & =\operatorname{Rp~103.500,-/hari~} \\
\operatorname{Rp~103.500~x~365~hari~} & =\operatorname{Rp} 37.777 .500, \text {-/tahun }
\end{array}
$$

\subsection{Biaya Instalasi Awal (Initial Installation Cost)}

Perhitungan biaya instalasi awal dengan menggunakan persamaan 11 sebagai berikut :

$$
\begin{aligned}
& \mathrm{IIC}=\mathrm{Rp} 146.912 .760+\mathrm{Rp} 3.000 .000 \\
& + \text { Rp 6.400.000 } \\
& =\operatorname{Rp~156.312.760,-~}
\end{aligned}
$$

\subsection{Arus Kas Bersih Tahunan (Annual Net Cash Flow)}

Perhitungan arus kas bersih tahunan dengan menggunakan persamaan 12 adalah sebagai berikut :

$$
\begin{aligned}
\mathrm{CF}_{\mathrm{N}} & =\operatorname{Rp} 37.777 .500-\operatorname{Rp} 5.000 .000 \\
= & \operatorname{Rp} 32.777 .500,-
\end{aligned}
$$

\subsection{Periode Pengembalian (Payback Period)}

Perhitungan periode pengembalian dengan menggunakan persamaan 13 sebagai berikut :

$$
\begin{aligned}
\mathrm{PP} & =\frac{\mathrm{Rp} 156.312 .760}{\mathrm{Rp} 32.777 .500} \\
& =4,77 \text { tahun } \approx 4 \text { tahun } 9 \text { bulan }
\end{aligned}
$$

\subsection{Pembayaran Tahunan (Yearly Payment)}

Perhitungan pembayaran tahunan dengan menggunakan persamaan 14 sebagai berikut :

$$
\begin{aligned}
\text { PI } & =156.312 .760 \times \frac{10 \% \times(1+10 \%)^{10}}{(1+10 \%)^{10}-1} \\
& =\operatorname{Rp~25.439.181,-}
\end{aligned}
$$

\subsection{Titik Impas (Break Even Point)}

$$
\begin{aligned}
\mathrm{BEP}= & \operatorname{Rp} 254,391,820+\operatorname{Rp} 21.873 .000+ \\
& \operatorname{Rp50.000.000} \\
= & \operatorname{Rp} 326.264 .820,-
\end{aligned}
$$

Didapatkan titik impas saat memasuki periode ke-9 dengan nilai surplus sebesarRp 13.732.680,- 


\subsection{Arus Kas Tahunan (Annual Cash Flow)}

Perhitungan arus kas tahunan dengan menggunakan persamaan 16 sebagai berikut :

$$
\begin{aligned}
\mathrm{CF}_{\mathrm{A}}= & \operatorname{Rp} 32.777 .500-\operatorname{Rp} 25.439 .181 \\
& =\operatorname{Rp~7.338.318,-}
\end{aligned}
$$

\subsection{Arus Kas Kumulatif (CumulativeCashFlow)}

Untuk mencari arus kas kumulatif, harus didapatkan nilai cash flow out selama periode yang diinginkan. Cash flow out dapat dicari dengan menggunakan persamaan 18 berikut :

$$
\begin{aligned}
& \mathrm{CF}_{\text {out }}=\operatorname{Rp} 156 \cdot 312.760+\operatorname{Rp} 254,391,820+ \\
& \text { Rp 59.961.000 + Rp 100.000.000 } \\
& =\operatorname{Rp} 570,665,580 \text {,- }
\end{aligned}
$$

Perhitungan arus kas kumulatif setelah $\mathrm{CF}_{\text {out }}$ didapatkan sebagai berikut :

$$
\begin{aligned}
& \mathrm{CF}_{\mathrm{C}, \mathrm{n}}=\mathrm{Rp} 755.550 .000-\mathrm{Rp} 570,665,580,- \\
& =\operatorname{Rp~184,884,420,-}
\end{aligned}
$$

\subsection{Gross Benefit Cost Ratio (Gross B/C)}

Perhitungan Gross B/C dengan menggunakan persamaan 19 adalah sebagai berikut :

$$
\begin{aligned}
\text { Gross B/C } & =\frac{\operatorname{Rp} 755.550 .000}{\operatorname{Rp} 570.665 .580} \\
& =1,32
\end{aligned}
$$

\subsection{Return On Investment (ROI)}

ROI dapat dicari dengan menggunakan persamaan 20 berikut :

$$
\begin{aligned}
\text { ROI } & =\frac{\operatorname{Rp~755.550.000-Rp~570.665.580~}}{\operatorname{Rp} 570.665 .580} \\
& =0,32398 \approx 32 \%
\end{aligned}
$$

\subsection{NetPresentValue (NPV)}

NPV dengan persamaan 21 didapatkan hasil sebagai berikut :

$$
\operatorname{NPV}(i, \mathrm{~N})=\operatorname{Rp} 100.381 .535,-
$$

\subsection{Internal Rate of Return (IRR)}

Analisis IRR di asumsikan tingkat suku bunga rendah $\mathrm{NPV}_{\mathrm{a}}$ sebesar $10 \%$ dan suku bunga tinggi $\mathrm{NPV}_{\mathrm{b}}$ sebesar $12 \%$.

Perhitungan IRRdengan menggunakan persamaan 22 sebagai berikut :

$$
\begin{aligned}
\operatorname{IRR}=10 \% & +\frac{100.381 .535}{100.381 .535-34.079 .221} \times(15 \%-10 \%) \\
& =19,73 \%
\end{aligned}
$$

\section{Kesimpulan}

1. Kapasitas baterai yang diperlukan dengan memperhatikan SOC $30 \%$ adalah 48 volt dengan kapasitas baterai 800 Ah sehingga didapatkan waktu kemampuan baterai menggerakkan motor listrik DC selama 1,41 jam $\approx 1$ jam 25 menit.

2. Kecepatan kapal wisata dengan menggunakan motor listrik DC adalah 6,7 knots dan jarak tempuh kapal wisata dengan menggunakan kapasitas baterai $70 \%$ yaitu 17,4 km.

3. Penghematan biaya penggunaan BBM HSDdalam setahun setelah penerapan hybrid system sebesar Rp $37,777,500,-(60 \%)$.

4. Keputusan pelaksanaan proyek dan kelayakan investasi menggunakan metode Gross B/C, ROI, NPV dan IRR. Keputusan yang didapatkan adalah proyek dapat dilaksanakan dan investasi layak serta menguntungkan.

\section{Referensi}

[1] Sudiono dan Antoko, Bambang, 2008, "Perancangan dan Pembuatan Kapal Wisata dengan Motor Generator Listrik Tenaga Surya Sebagai Energi Alternatif Penggerak Propeler, Surabaya : Institut Teknologi Sepuluh Nopember Surabaya.

[2] Martian Dwi Sunarto, Natanael dan Budiarto, Untung, 2014 "Studi Perancangan Kapal Wisata Trimaran Hybrid Untuk Perairan Kepulauan Karimun Jawa", Semarang : UNDIP.

[3] Sasmito Hadi, Eko dan Budiarto, Untung, 2008, "Kajian Teknis Propeller-Engine Matching pada Kapal Ikan Tradisional dengan Menggunakan Motor Listrik Hybrid dari Solar Cell dan Genset sebagai Mesin Penggerak Utama Kapal di Kabupaten Pasuruan Jawa Timur", Jawa Timur : UNDIP.

[4] Zulkifli, 2011, "Perencanaan Pemanfaatan Energi Surya Sebagai Energi Alternatif Untuk Kebutuhan Listrik Pada KLM. PINISI 360 GRT', Makassar : UNHAS.

[5] Sullivan, Gregor, 2014, "Monocrystalline vs Polycrystalline Solar Panels",http://www.sunnyray.org/Monocrystalline-vspolycrystalline-solar-panels.htm, (diakses pada tanggal 12 Oktober 2015, jam 12:14 wib).

[6] www.janaloka.com/potensi-energi-matahari-di-indonesia/, (diakses pada tanggal 26 Februari 2016, jam 16:22 wib).

[7] http://www.panelsurya.com/index.php/id/charge-controller/carakerja-solar-controller, (diakses pada tanggal 29 Juni 2015, jam 15.05 wib).

[8] Jung, Jinho dan E.Tyner, Wallace, 2014, "Economic and policy analysis for solar PV systems in Indiana”, Indianapolis : Purdue University.

[9] Tzouanas, Vassilios, 2012, "Study of A Photo Voltaic (PV) System Using Excel : Economic Analysis, Modeling, Simulation and Optimization", Texas : University of Houston.

[10] https://goo.gl/StmJZk, (diakses pada tanggal 17 Oktober 2015 , jam 12:45 wib).

[11] http://goo.gl/oJLXX2, (diakses pada tanggal 17 Oktober 2015, jam 13:30 wib).

[12] Botchkarev, Alexei dan Andru, Peter, 2011, "A Return on Investment as a Metric for Evaluating Information Systems: Taxonomy and Application", Canada : Ryerson University. 
[13] https://www.business-case-analysis.com/return-oninvestment.html\#compare, (diakses pada tanggal 17 Oktober 2015, jam 11:25 wib)

[14] https://en.wikipedia.org/wiki/Net_present_value, (diakses pada tanggal 16 Oktober 2015, jam 16:20 wib).

[15] http://goo.gl/CaQaoJ, (diakses pada tanggal 16 Oktober 2015, jam 17:00 wib)

\section{Biography}

Ferdyanto, lahir di Jakarta pada tanggal 28 Juni 1984. Menyelesaikan pendidikan S-1 Teknik Perkapalan di Universitas Pembangunan Nasional "Veteran" Jakarta Tahun 2006 dan S-2 Teknik Elektro di Universitas Tanjungpura Pontianak Tahun 2016. Sejak tahun 2007 sampai dengan sekarang bekerja sebagai Area Manager Kalimantan Barat di PT Surveyor Indonesia (Persero). 
